\title{
Eksplorasi hubungan emotional exhaustion dan work culture pada teacher performance
}

\author{
Ina Ratnasari' Nurleila Jum 'ati ${ }^{2}$ \\ 1\& SDN Banjarsugihan V/617 Surabaya \\ inaratna06@gmail.com
}

\begin{abstract}
This study aims to explore the effect of emotional exhaustion and work culture on teacher performance. In this study, using a proportional random sampling technique and a sample of 69 teachers who were then directed to fill out the research questionnaire. The analysis technique used is multiple linear regression with data processing using SPSS version 22 statistics. Based on the results of data analysis, it was found that the t-test $t$ value was significant for the emotional exhaustion variable of $t=0.006<0.05$. Thus emotional exhaustion has a significant effect on teacher performance. And the significant value for work culture is $t=0.000<0.05$. Thus work culture has a significant influence on teacher performance. While the test results using the F test can be said that all independent variables (emotional exhaustion, and work culture) simultaneously affect teacher performance. This can be seen from the significant level of $F$, which is $0.000<0.05$.
\end{abstract}

Keywords: Emotional exhaustion, work culture, teacher performance.

\begin{abstract}
Abstrak: Penelitian ini bertujuan untuk mengeksplorasi pengaruh emotional exhaustion dan budaya kerja terhadap kinerja guru. Pada penelitian ini menggunakan teknik proportional random sampling dan sampel yang digunakan sebanyak 69 guru yang kemudian diarahkan untuk mengisi kuesioner penelitian. Teknik analisis yang digunakan adalah regresi linier berganda dengan pengolahan data menggunakan statistik dengan alat SPSS versi 22 . Berdasarkan hasil analisis data ditemukan bahwa t-test $\mathrm{t}$ value signifikan untuk variabel emotional exhaustion sebesar $\mathrm{t}=0,006<0,05$. Dengan demikian emotional exhaustion memiliki pengaruh yang signifikan terhadap kinerja guru. Dan nilai signifikan untuk budaya kerja adalah $\mathrm{t}=0,000<0,05$. Dengan demikian budaya kerja memiliki pengaruh yang signifikan terhadap kinerja guru. Sedangkan hasil pengujian dengan menggunakan uji $F$ dapat dikatakan bahwa semua variabel bebas (emotional exhaustion, dan budaya kerja) berpengaruh secara bersamaan terhadap kinerja guru. Hal ini dapat dilihat dari tingkat signifikan $\mathrm{F}$ yaitu $0,000<0,05$.
\end{abstract}

Kata Kunci: Emotional exhaustion, work culture, teacher performance. 


\section{PENDAHULUAN}

Posisi Guru dalam dunia pendidikan adalah garda terdepan dan sentral terlaksananya proses pembelajaran. Dalam hal ini, UU No. 20 tahun 2003 tentang sistem pendidikan nasional (Kurniasih dan Sani, 2014) memaparkan pengertian pendidikan sebagai: usaha sadar dan terencana untuk mewujudkan suasana belajar dan proses pembelajaran agar peserta didik secara aktif mengembangkan potensi dirinya untuk memiliki kekuatan spiritual keagamaan, pengendalian diri, kepribadian, kecerdasan, akhlak mulia, serta keterampilan yang diperlukan dirinya, masyarakat, bangsa dan negara. Maka berkaitan dengan kinerja guru diperlukan adanya totalitas, dedikasi, maupun loyalitas sebagai seorang pendidik yang pencetak bekal-bekal sumber daya manusia (SDM). Tujuan pembelajaran yang diinginkan tentu yang optimal, untuk itu ada beberapa hal yang perlu diperhatikan oleh guru sebagai pendidikberkaitan dengan kinerjanya.

Menurut Mangkunegara (2011), bahwa kinerja adalah hasil kerja secara kualitas dan kuantitas yang dicapai oleh seseorang karyawan dalam melakukan tugasnya sesuai dengan tanggung jawab yang diberikan kepadanya.Kinerja adalah prestasi kerja yang merupakan hasil dari implementasi rencana kerja yang dibuat oleh suatu institusi yang dilaksanakan oleh pimpinan dan karyawan (SDM) yang bekerja di instasi baik pemerintah maupun perusahaan (bisnis) untuk mencapai tujuan organisasi (Abdullah, 2014). Sebagai seorang gurusudah seharusnya melakukan pekerjaannya dengan tanggung jawab dan professional sehingga dapat melaksanakan tugasnya dengan sebaik-baiknya. Penyelesaian dari tugas dan kegiatan yang dilakukan oleh guru akan menentukan tinggi rendahnya kinerja yang dimiliki.

Keberhasilan dan kinerja guru dapat terhambat dengan adanya kualitas guru yang mengalami kelelahan emosional. Churiyah, 2011) menyatakan bahwa seseorang yang mengalami emotional exhaustion ditandai dengan terkurasnya sumber sumber emosional, misalnya perasaan frustasi, putus asa, sedih, tidak berdaya, tertekan terhadap pekerjaan dan merasa terbelenggu oleh tugas-tugas dalam pekerjaan sehingga seseorang tersebut merasa tidak mampu memberikan pelayanan secara psikologis. Ketika realitas yang ada tidak mendukung idealisme mereka, maka mereka tetap berupaya mencapai idealisme tersebut sampai akhirnya sumber diri mereka terkuras, sehingga mengalami kelelahan atau frustasi yang disebabkan terhalangnya pencapaian harapan. Sedangkan menurut Maslach dan Jackson (1996) emotional exhaustion adalah suatu perasaan emosional yang berlebihan dan sumber daya emosional seseorang yang telah habis yang dialirkan oleh kontak seseorang dengan orang lain.

Faktor lain yang mempengaruhi kinerja guru adalah budaya kerja. Menurut Schein (2014) mendefinisikan bahwa budaya kerja merupakan suatu pola asumsi dasar yang diciptakan, ditemukan, atau dikembangkan oleh kelompok tertentu sebagai pembelajaran untuk mengatasi masalah adaptasi eksternal dan integrase internal yang terjadi dalam organisasi. Budaya kerja pada sebuah organisasi terbentuk sejak satuan kerja atau 
organisasi tersebut berdiri. Pembentukan budaya kerja terjadi ketika suatu satuan kerja atau organisasi menghadapi suatu permasalahan yang berkenaan dengan keberlangsungan suatu organisasi yang menyangkut perubahan-perubahan eksternal maupun internal (Safrizal dan Chan, 2014). Menurut Schein (2014) budaya kerja yaitu pada dasarnya menentukan kualitas seseorang dalam bekerja. Budaya kerja dapat dilihat dari kebiasaan, peraturan, dan nilai-nilai. Budaya kerja yang tidak efektif antara guru dan kepala sekolah tentunya akan berpengaruh pada kinerja guru. Pengaruh ini dapat dilihat dari adanya pelanggaran yang dilakukan guru yaitu merokok di sekolah, keluar masuk kelas.Maka dari itu untuk menghindari kelelahan dalam proses pembelajaran seorang guru hendaknya pandai menciptakan cara mengajar yang mampu menimbulkan semangat dalam proses belajar mengajar disekolah. Dan dari pihak sekolah harus mampu menekan budaya kerja yang kurang baik. Dapat disimpulkan dari uraian diatas bahwa kinerja guru dapat tercapai apabila ada kerjasama yang baik antara antara kepala sekolah dan guru sehingga dapat mencapai tujuan awal dari suatu pendidikan.

\section{TINJAUAN TEORITIS}

\section{Kinerja Guru}

Kinerja atau performance merupakan gambaran mengenai tingkat pencapaian pelaksanaan suatu program kegiatan atau kebijakan dalam mewujudkan sasaran, tujuan, visi, misi organisasi yang dituangkan melalui perencanaan strategis suatu organisasi (Moeheriono, 2012). Aktivitas untuk menentukan berhasil tidaknya suatu pekerjaan yang dilakukan dalam organisasi adalah penilaian pelaksanaan seluruh kegiatan yang telah direncanakan sebelumnya. Aktivitas ini lazimnya disebut penilaian kinerja.

Menurut Rivai dan Prawironegoro (2015) kinerja guru dapat dirumuskan sebagai unjuk kerja yang dicapai, berupa prestasi (kualitas inidividu) yang diperlihatkan (tampilan atau unjuk kerja) dibidang yang menjadi tanggung jawabnya (tugas fungsional) dalam bentuk kemampuan kerja (Rivai dan Prawironegoro, 2015). Untuk dapat mengetahui dan mengungkapkan kemampuan dalam mengajar sebagai salah satu aspek kelayakan kemampuan guru, digunakan penilaian kemampuan sebagai berikut:

1. Keterampilan menyusun rencana pengajaran. Ketrampilan menyusun rencana pengajaran terdiri dari merencanakan pengelolaan kegiatan belajar-mengajar.

2. Kemampuan guru dalam merencanakan pengelolaan kegiatan belajar-mengajar meliputi keterampilan merumuskan, menentukan metode, menentukan langkahlangkah mengajar, dan menentukan cara-cara memotivasi murid. Merencanakan pengorganisasian bahan pengajaran meliputi kemampuan guru dalam merencanakan pengorganisasian bahan pembelajaran meliputi ketrampilan berpedoman pada bahan pengajaran yang tercantum dalam kurikulum, memilih dengan tepat bahan sesuai 
dengan karakteristik murid, dan menyusun bahan pengajaran sesuai dengan taraf kemampuan berpikirmurid.

Sudjana (2010) mendefinisikan kinerja guru itu dengan "kemampuan guru dalam berbagai ketrampilan mengajar, membimbing, menilai, menggunakan alat bantu pengajaran, bergaul atau berkomunikasi dengan siswa, ketrampilan menyusun persiapan atau perencanaan mengajar, ketrampilan melaksanakan administrasi kelas dan lain-lain" Menurut Supardi (2014) mengemukakan indikator yang berkaitan dengan variabel kinerja guru meliputi:

a. Kualitas kerja.

Indikator kualitas kerja guru terdiri dari menguasai bahan pelajaran, mengelola proses belajar mengajar, mengelola kelas.

b. Kecepatan/ketepatan kerja.

Indikator kecepatan/ketepatan kerja guru berhubungan dengan penggunaan media atau sumber belajar, menguasai landasan pendidikan, merencanakan program pembelajaran.

c. Inisiatif dalam kerja.

Indikator inisiatif dalam kerja guru terdiri dari memimpin kelas, mengelola interaksi belajar mengajar, melakukan penilaian hasil belajar siswa.

d. Kemampuan kerja.

Indikator kemampuan kerja guru meliputi penggunaan berbagai metode dalam pembelajaran, memahami dan melaksanakan fungsi dan layanan bimbingan penyuluhan.

e. Komunikasi.

Indikator komunikasi dalam hal ini dapat memahami dan menyelenggarakan administrasi sekolah, memahami dan dapat menafsirkan hasil-hasil penelitian untuk peningkatan kualitas pembelajaran.

\section{Emotional exhaustion}

Emotional exhaustion didefinisikan oleh Churiyah (2011) sebagai kelelahan para individu yang berhubungan dengan perasaan pribadi yang ditandai dengan rasa tidak berdaya dan depresi. Hubungan yang tidak seimbang antara pekerjaan dan diri sendiri dapat menimbulkan ketegangan emosional yang berujung pada terkurasnya sumbersumber emosi.

Emotional exhaustion selalu didahului oleh suatu gejala umum, yaitu timbulnya rasa cemas setiap ingin mulai bekerja, yang kemudian mengarah pada perasaan tidak berdaya menghadapi tuntutan pekerjaan. Emotional exhaustion adalah permulaan terjadinya kemunduran kepribadian yang mendorong kembalinya perasaan kurang percaya diri pada seorang pegawai sehingga berdampak pada komitmen organisasional 
IMKA Implementasi Manajemen \& Kewirausahaan - April, Vol. 1, No. 1, 60-73, 2021

pegawai pada organisasi (Kusriyani et al., 2016). Dalam penelitian Schaufeli dan Enzmann (1998) ) terdapat 3 indikator emotional exhaustion antara lain :

1. Fisik. Emotional exhaustion dapat mempengaruhi kondisi tubuh personal seperti mengakibatkan problem tidur dan mudah lelah secara fisik.

2. Emosi. Emosi terdapat di dalam komponen afektif manusia. Kelelahan di dalam hal emosi yaitu : mudah lupa, sulit konsentrasi, mengalami kebosanan, dan mudah marah.

3. Mental. Mental merupakan kelelahan yang berupa kecemasan dan ketegangan, komunikasi tidak efektif, mengasingkan diri, ketidak puasan kerja, serta menurunnya fungsi intelektual.

\section{Budaya Kerja}

Budaya kerja adalah suatu falsafah yang didasari oleh pandangan hidup sebagai nilai - nilai yang menjadi sifat, kebiasaan dan kekuatan pendorong, membudaya dalam kehidupan suatu kelompok masyarakat atau organisasi, kemudian tercermin dari sikap menjadi perilaku, kepercayaan, cita-cita, pendapat dan tindakan yang terwujud sebagai "kerja" atau "bekerja" (Arianto, 2013). Budaya Kerja pada sebuah organisasi terbentuk sejak satuan kerja atau organisasi tersebut berdiri.Pembentukan budaya kerja terjadi ketika suatu satuan kerja atau organisasi menghadapi suatu permasalahan yang berkenaan dengan keberlangsungan suatu organisasi yang menyangkut perubahan-perubahan eksternal maupun internal (Safrizal dan Chan 2014). Menurut Schein (2014) budaya kerja yaitu pada dasarnya menentukan kualitas seseorang dalam bekerja. Budaya kerja dapat dilihat dari kebiasaan, peraturan, dan nilai-nilai. Budaya kerja yang tidak efektif antara guru dan kepala sekolah tentunya akan berpengaruh pada kinerja guru. Pengaruh ini dapat dilihat dari adanya pelanggaran yang dilakukan guru yaitu merokok di sekolah, keluar masuk kelas. Menurut Schein (2014) mengemukakan indikator yang terkait dengan budaya kerja adalah:

1. Mau menerima arahan pimpinan;

Para guru harus siap menerima arahan dari pimpinan demi tercapainya suatu tujuan bersama.

2. Senang menerima tanggung jawab kerja;

Sikap dan perilaku seseorang untuk melaksanakan tugas dan kewajibannya yang seharusnya dilakukan terhadap suatu pekerjaan.

3. Kerja sebagai ibadah;

Melakukan suatu pekerjaan dengan mendahulukan niat bekerja untuk diri sendiri, keluarga dan untuk melayani masyarakat dengan ikhlas.

4. Melaksanakan pekerjaan sesuai tugas;

Melakukan suatu pekerjaan sesuai tugas yang telah diberikan oleh atasan.

5. Dapat mengatasi kendala kerja;

Guru dapat menyelesaikan suatu masalah jika ada kendala dari suatu pekerjaan. 
6. Dapat menyusun laporan kerja.

Guru dapat menyusun dan membuat laporan kerja sesuai dengan tugas - tugas yang telah diberikan atasan.

\section{Research Terdahulu}

Sudirno dan Nurvianti (2015), dalam penelitian yang berjudul "Konflik peran dan emotional exhaustion pengaruhnya terhadap kinerja dosen pada Universitas Majalengka". Penelitian ini bertujuan untuk seberapa besar pengaruh konflik peran emotional exhaustionterhadap kinerja dosen, baik secara parsial maupun simultan pada Universitas Majalengka. Analisis deskriktif dan verifikatif. Dari variabel konflik peran (X1), emotional exhaustion(X2) sebagai variabel independen secara bersama-sama berpengaruh terhadap kinerja dosen (Y) Terdapat persamaan variabel yaitu emotional exhaustionyang berpengaruh terhadap kinerja guru. Terdapat perbedaan variabel yang mempengaruhi kinerja guru yaitu kedidsiplinan dan konflik peran (X1). Terdapat perbedaan tempat penelitian serta subyek penelitian.

Yulistini, Putra (2015) dalam penelitian yang berjudul "Pengaruh emotional exhaustion terhadap kepuasan kerja guru SMK di Denpasar". Untuk mengetahui pengaruh emotional exhaustionterhadap kepuasan kerja pada guru SMK di Denpasar Analisis Regresi linier sederhana Hasil pengujian menunjukkan bahwa emotional exhaustionberpengaruh negatif terhadap kepuasan kerja. Terdapat persamaan variabel yaitu emotional exhaustion(X1) Terdapat perbedaan variabel (Y) kepuasan kerja.

Arianto (2013) dalam penelitian yang berjudul "Pengaruh Kedisiplinan, Lingkungan kerja dan Budaya kerja terhadap Kinerja Tenaga Pengajar”. Bertujuan untuk: menganalisis pengaruh kedisiplinan kerja, lingkungan kerja dan budaya kerja terhadap kinerja tenaga pengajar. Analisis regresi linier berganda Hasil pengujian menunjukkan bahwa kedisiplinan kerja, lingkungan kerja tidak berpengaruh terhadap kinerja. Secara bersama-sama kedispilinan kerja, lingkungan kerja dan budaya berpengaruh terhadap kinerja tenaga pengajar. Terdapat persamaanvariabel yaitu (x3) budaya kerja yang berpengaruh terhadap (Y) Kinerja. Terdapat perbedaan variabel (x1) dan (x2) yang mempengaruhi(Y). terdapat perbedaan jumlah variabel yang diteliti. Terdapat perbedaan tempat penelitian serta subyek penelitian.

Safrizal dan Chan (2014) dalam penelitian yang berjudul "Pengaruh Budaya Kerja, Kemampuan dan Komitmen Pegawai terhadap Kinerja Pegawai serta dampaknya pada Kinerja Dinas Pertambangan dan Energi Aceh”. Untuk mengetahui pengaruh budaya kerja, kemampuan pegawai, dan komitmen pegawai terhadap kinerja pegawai baik secara parsial maupun simultan Teknik Random Sampling Menunjukkan bahwa budaya kerja, kemampuan pegawai dan komitmen pegawai berpengaruh secara parsial dan simultan terhadap kinerja pegawai dan juga terhadap kinerja Dinas Pertambangan dan Energi Aceh. Terdapat persamaan variabel (x1) yaitu Budaya kerja yang berpengaruh terhadap 
(Y) Kinerja guru. Terdapat perbedaan variabel (x2) dan (x3) yang mempengaruhi Y. terdapat perbedaan jumlah variabel yang diteliti, serta subyek penelitian.

Widhaswara (2017) dalam penelitian yang berjudul "Pengaruh Budaya Kerja, Lingkungan Kerja, dan Stres Kerja terhadap Karyawan PT Suling Mas Tri Tunggal Abadi Tulungagung”. Untuk mengetahui Pengaruh Budaya Kerja, Lingkungan Kerja, dan Stres Kerja secara parsial dan simultan terhadap Karyawan PT Suling Mas Tri Tunggal Abadi Tulungagung. Analisis Kuantitatif dan Deskriptif. Dari variabel Budaya Kerja, Lingkungan Kerja, dan Stres Kerja berpengaruh secara parsial dan simultan terhadap Karyawan PT Suling Mas Tri Tunggal Abadi Tulungagung. Terdapat persamaan variabel yaitu budaya kerja, stress kerja kinerja. Terdapat perbedaan variabel lingkungan kerja yang mempengaruhi kinerja. Terdapat perbedaan jumlah variabel yang diteliti. Terdapat perbedaan tempat penelitian dan subyek penelitian.

\section{Hipotesis penelitian}

Berdasarkan kerangka berpikir yang telah ditetapkan, maka dirumuskan hipotesis sebagai berikut:

1. Terdapat pengaruh yang signifikan antara variabel emotional exhaustion (X1) terhadap kinerja guru (Y) di SDN wilayah kecamatan Tandes.

2. Terdapat pengaruh yang signifikan antara variabel budaya kerja (X2) terhadap kinerja guru (Y) di SDN wilayah kecamatan Tandes.

3. Terdapat pengaruh yang signifikan antara variabel emotional exhaustion (X1) dan variabel budaya kerja (X2) secara bersama - sama terhadap kinerja guru (Y) di SDN wilayah kecamatan Tandes.

\section{METODE PENELITIAN}

Metode penelitian yang digunakan pada studi ini adalah metode kuantitatif yang menitik beratkan pada pengujian hipotesis (Sugiyono, 2012). Teknik dalam pengambilan sampel penelitian ini adalah purposive proportional random sampling. Purposive sampling menurut Sugiyono adalah teknik penentuan sampel dengan pertimbangan tertentu (Sugiyono,2012). Adapun pertimbangan tertentu dalam penelitian ini antara lain:

1. Dari tahun ke tahun ada kejadian / fenomena dan kendala-kendala yang harus dihadapi para guru kelas V dan VI dalam mempersiapkan siswanya untuk menghadapi ujian sekolah, baik dari siswa, orang tua, sekolah dan pemerintah.

2. Usaha dan berbagai upaya yang harus dilakukan guru kelas V dan VI untuk membimbing para siswa mencapai nilai yang maksimal dalam ujian dan dapat lulus dengan nilai yang baik.

Sedangkan untuk Responden yang menjadi sampel dalam penelitian ini yaitu sebanyak 69 tenaga pengajar SDN wilayah Kecamatan Tandes. Dalam penelitian ini jenis 
instrumen yang digunakan adalah kuisioner yang disebarkan secara langsung kepada responden. Kemudian data yang diperoleh dari hasil pengisian kuisioner akan dianalisis dengan menghitung masing-masing skor dari setiap pertanyaan. Selanjutnya akan dapat diambil kesimpulan mengenai kondisi setiap item pertanyaan pada objek yang diteliti. Kuisioner yang digunakan dalam hal ini adalah kuisioner tertutup, yakni kuisioner yang sudah disediakan jawabannya sehingga responden tinggal memilih dan dijawab secara langsung oleh responden. Selain itu item pertanyaan yang diajukan dan disediakan pula alternatif jawaban. Dengan menggunakan rentang skala 1 sampai 5, dimana semakin tinggi nilai skor yang diberikan maka akan semakin baik nilai indikator tersebut. Adapun perincian penilaian tersebut adalah:

1. Jawaban SS (Sangat Setuju) dengan skor nilai 5

2. Jawaban S (Setuju) dengan skor nilai 4

3. Jawaban RR (Ragu-ragu) dengan skor nilai 3

4. Jawaban TS (Tidak setuju) dengan skor nilai 2

5. Jawaban STS (Sangat Tidak Setuju) dengan skor nilai 1

Selanjutnya, setelah data terkumpul data kemudian diolah menggunakan SPSS menggunakan teknik analisis regresi linier berganda, kemudian diinterpretasikan untuk hasil olahan datanya.

\section{HASIL DAN PEMBAHASAN}

\section{Persamaan Regresi Linier Berganda}

Analisis ini digunakan untuk menganalisis pengaruh dari berbagai variabel independen, yaitu emotional exhaustion (X1), dan budaya kerja (X2), terhadap satu variabel dependen, yaitu kinerja guru (Y) (Ghozali, 2011). Ringkasan hasil pengolahan data dengan menggunakan program SPSS tersebut adalah sebagai berikut:

Coefficients ${ }^{\mathrm{a}}$

\begin{tabular}{|rl|r|r|r|r|r|}
\hline Model & \multicolumn{2}{|c|}{ Unstandardized Coefficients } & $\begin{array}{c}\text { Standardized } \\
\text { Coefficients }\end{array}$ & \multirow{2}{*}{ Sig. } \\
\cline { 3 - 6 } & \multicolumn{1}{|c|}{ B } & Std. Error & Beta & & \\
\hline \multirow{2}{*}{1} & (Constant) & 12.575 & 2.580 & & 4.873 & .000 \\
& Kelelahan Emosional & .452 & .159 & .355 & 2.848 & .006 \\
& Budaya Kerja & .364 & .089 & .508 & 4.078 & .000 \\
\hline
\end{tabular}

a. Dependent Variable: Kinerja Guru

Dari hasil tersebut apabila ditulis dalam bentuk unstandardized dari persamaan regresinya adalah sebagai berikut: 
IMKA Implementasi Manajemen \& Kewirausahaan - April, Vol. 1, No. 1, 60-73, 2021

$$
\mathbf{Y}=\mathbf{1 2 , 5 7 5}+\mathbf{0 , 4 5 2} \mathrm{X} 1+\mathbf{0 , 3 6 4} \times 2
$$

Nilai konstanta sebesar 12,575. Nilai konstanta bernilai positif artinya jika skor variabel kelelahan emosional, dan budaya kerja dianggap tidak ada atau sama dengan 0 , maka skor kinerja guru akan semakin bertambah.

a. Koefisien regresi variabel emotional exhaustion menunjukkan nilai positif yang artinya jika emotional exhaustion yang diberikan semakin bagus maka kinerja guruakan meningkat. Nilai koefisien regresi emotional exhaustion menunjukkan nilai sebesar b1 = 0,452 yang artinya jika nilai variabel emotional exhaustion mengalami perubahan sebesar satu satuan dan nilai variabel lainnya (budaya kerja) dianggap konstan maka nilai variabel kinerja guruakan mengalami perubahan sebesar 0,452 dikali satu satuan.

b. Koefisien regresi variabel budaya kerja menunjukkan nilai positif yang artinya jika budaya kerja yang diberikan semakin bagus maka kinerja guruakan meningkat. Nilai koefisien regresi menunjukkan nilai sebesar b2 $=0,364$ yang artinya jika nilai variabel budaya kerja mengalami perubahan sebesar satu satuan dan nilai variabel lainnya (emotional exhaustion) dianggap konstan maka nilai variabel kinerja guruakan mengalami perubahan sebesar 0,364 dikali satu satuan.

c. Kedua variabel independen yang di uji secara individual yang memiliki nilai yang lebih tinggi atau yang lebih besar dari variabel lain adalah variabel emotional exhaustion (dengan koefisien 0,452).

\section{Analisis Koefisien Determinasi}

Berikut adalah tabel hasil R-Square dengan perhitungan statistik dengan menggunakan SPSS versi 20:

\begin{tabular}{|l|c|r|r|r|}
\hline Model & R & \multicolumn{1}{|c|}{ R Square } & Adjusted R Square & Std. Error of the Estimate \\
\hline 1 & $.827^{\mathrm{a}}$ & .684 & .675 & 2.96225 \\
\hline
\end{tabular}

a. Predictors: (Constant), Budaya Kerja, Kelelahan Emosional

b. Dependent Variable: Kinerja Guru

Berdasarkan tabel bahwa korelasi antara kinerja guru dengan seluruh variabel bebas (emotional exhaustion, dan budaya kerja) adalah kuat karena $\mathrm{R}=0,827>0,5$ sedangkan R-Square sebesar 0,684 berarti 68,4\% (0,684 x 100\%) variasi atau perubahan dari kinerja guru dipengaruhi secara bersama-sama oleh emotional exhaustion, dan budaya kerjasedangkan sisanya $31,6 \%(100 \%-68,4 \%=31,6 \%)$ variasi atau perubahan dari kinerja guru disebabkan oleh variabel lain yang tidak disertakan dalam penelitian ini. 


\section{Uji Pengaruh Simultan (Uji F)}

Uji $\mathrm{F}$ digunakan untuk menguji ada tidaknya pengaruh variabel-variabel independen dengan variabel dependen secara simultan (bersama-sama). Berikut adalah tabel hasil uji $\mathrm{F}$ dengan perhitungan statistik menggunakan SPSS:

ANOVA $^{\mathrm{a}}$

\begin{tabular}{|rl|r|r|r|r|r|}
\hline Model & & Sum of Squares & \multicolumn{1}{|c|}{ df } & Mean Square & \multicolumn{1}{c|}{ F } & Sig. \\
\hline \multirow{2}{*}{1} & Regression & 1255.841 & 2 & 627.921 & 71.559 & $.000^{\mathrm{b}}$ \\
& Residual & 579.144 & 66 & 8.775 & & \\
& Total & 1834.986 & 68 & & & \\
\hline
\end{tabular}

a. Dependent Variable: Kinerja Guru

b. Predictors: (Constant), Budaya Kerja, Kelelahan Emosional

Berdasarkan tabel dapat dikatakan bahwa seluruh variabel bebas (emotional exhaustion dan budaya kerja) berpengaruh secara simultan (bersama-sama) pada kinerja guru. Hal itu terlihat dari tingkat signifikansi $\mathrm{F}$ yang sebesar $0,000<0,05$.

\section{Uji Pengaruh Parsial (Uji t)}

Uji t yaitu suatu uji untuk mengetahui signifikansi pengaruh variabel bebas (kelelahan emosional, dan budaya kerja) secara parsial atau individual menerangkan variabel terikat (kinerja guru).

Coefficients $^{\mathbf{a}}$

\begin{tabular}{|c|c|c|c|c|c|c|}
\hline \multirow{2}{*}{\multicolumn{2}{|c|}{ Model }} & \multicolumn{2}{|c|}{ Unstandardized Coefficients } & \multirow{2}{*}{$\begin{array}{c}\text { Standardized } \\
\text { Coefficients }\end{array}$} & \multirow[t]{2}{*}{$\mathrm{t}$} & \multirow[t]{2}{*}{ Sig. } \\
\hline & & $\mathrm{B}$ & Std. Error & & & \\
\hline \multirow{3}{*}{1} & (Constant) & 12.575 & 2.580 & & 4.873 & .000 \\
\hline & Kelelahan Emosional & .452 & .159 & .355 & 2.848 & .006 \\
\hline & Budaya Kerja & .364 & .089 & .508 & 4.078 & .000 \\
\hline
\end{tabular}

a. Dependent Variable: Kinerja Guru

1. Signifikan emotional exhaustion sebesar $0,006<0,05$ berarti emotional exhaustion berpengaruh signifikan secara parsial pada kinerja guru.

2. Signifikan budaya kerja sebesar $0,000<0,05$ berarti budaya kerja berpegaruh signifikan secara parsial pada kinerja guru.

\section{PEMBAHASAN}

Dari hasil penelitian ini, berdasarkan karakteristik responden dengan jumlah sampel sebanyak 69 responden, dapat diketahui bahwa sebagian besar responden adalah laki-laki sebesar 52,2\% atau 36 orang, berdasarkan usia menunjukkan bahwa sebagian besar responden berusia 36 - 45 tahun berjumlah 39 orang atau sebesar 56,5\%. Sementara dari hasil rata-rata kinerja guru SDN di wilayah kecamatan Tandes di kategori mean sebesar 4,27 dikategorikan sangat tinggi. Sedangkan hasil untuk nilai rat-rata emotional 
exhaustionguru SDN di wilayah kecamatan Tandes di kategori mean sebesar 4,19 dikategorikan tinggi. Dan untuk hasil rata-rata budaya kerja guru SDN di wilayah kecamatan Tandes di kategori mean sebesar 4,29 dikategorikan sangat tinggi.

\section{Pengaruh Variabel Emotional exhaustion Terhadap Kinerja Guru}

Nilai koefisien regresi emotional exhaustion sebesar 0,452, hal ini berarti bahwa jika variabel emotional exhaustion berubah satu satuan, maka variabel Y (kinerja guru) berubah sebesar nilai koefisiennya yaitu sebesar 0,618 dengan asumsi variabel lainnya tetap. Nilai koefisien bertanda positif berarti arah hubungannya searah. Artinya jika emotional exhaustion meningkat maka kinerja guru akan meningkat. Nilai signifikansi t untuk emotional exhaustion sebesar $\mathrm{t}=0,006<0,05$. Dengan demikian variabel emotional exhaustion berpengaruh secara signifikan terhadap kinerja guru. Hal ini bisa disebabkan guru masih sering terbawa emosi dengan suasana yang ada dikelas. Pada indikator emosi dalam pernyataan saya sering merasa marah karena hal-hal yang terjadi diluar kontrol mendapatkan hasil mean 4,26. Dari hal ini dapat dilihat bahwa dari segi emotional exhaustion guru masih sering terbawa emosi dengan situasi yang ada dikelas. Hasil penelitian ini sama dengan hasil penelitian Yuli Kusdiah (2012) yang menyatakan bahwa emotional exhaustion berpengaruh secara signifikan terhadap kinerja guru, karena guru sering gelisah dan susah tidur ketika muridnya akan menghadapi ujian. Untuk mengatasi rasa gelisah dan susah tidur para guru menemukan cara yang efektif yaitu dengan melakukan kegiatan yang positif seperti: sholat Dhuha dan sholat malam, membuat soal yang dibagikan ke siswa sebagai latihan-latihan sebelum para siswa menghadapi ujian

\section{Pengaruh Variabel Budaya Kerja Terhadap Kinerja Guru}

Nilai koefisien regresi variabel X2 Budaya Kerja sebesar 0,364, hal ini berarti bahwa jika variabel budaya kerja berubah satu satuan, maka variabel Y (kinerja guru) berubah sebesar nilai koefisiennya yaitu sebesar 0,364 dengan asumsi variabel lainnya tetap. Nilai koefisien bertanda positif berarti arah hubungannya searah. Artinya jika budaya kerja meningkat maka kinerja guru akan meningkat. Nilai signifikansi t untuk variabel X2 budaya kerja sebesar $\mathrm{t}=0,000<0,05$. Dengan demikian variabel $\mathrm{X} 2$ budaya kerja berpengaruh secara signifikan terhadap variabel Y (kinerja guru). Hal ini bisa disebabkan para guru bangga jika sudah bekerja keras untuk menyelesaikan pekerjaan. Pada indikator melaksanakan pekerjaan sesuai tugas pada pernyataan saya merasa bangga jika telah bekerja keras untuk menyelesaikan pekerjaan mendapatkan hasil mean 4,38. Dari hal ini dapat dilihat bahwa dari segi budaya kerja para guru akan bangga jika mereka telah menyelesaikan pekerjaan yang telah diberikan oleh sekolah. Hasil penelitian ini sama dengan hasil penelitian Kurniawan (2012) yang menyatakan bahwa budaya kerja berpengaruh secara signifikan terhadap kinerja guru, karena para guru bersedia memberikan les tambahan kepada siswa tanpa diberi imbalan dari orang tua dan sekolah. 


\section{Pengaruh variabel emotional exhaustion, dan budaya kerja terhadap kinerja guru}

Korelasi antara kinerja guru dengan seluruh variabel bebas (kelelahan emosional, dan budaya kerja) adalah kuat karena $\mathrm{R}=0,827>0,5$ sedangkan $\mathrm{R}$-Square sebesar 0,684 berarti $68,4 \%(0,684 \times 100 \%)$ variasi atau perubahan dari kinerja guru dipengaruhi secara bersama-sama oleh kelelahan emosional, dan budaya kerjasedangkan sisanya 31,6 \% $(100 \%-68,4 \%=31,6 \%)$ variasi atau perubahan dari kinerja guru disebabkan oleh variabel lain yang tidak disertakan dalam penelitian ini. Seluruh variabel bebas (emotional exhaustion, dan budaya kerja) berpengaruh secara simultan (bersama-sama) pada kinerja guru. Hal itu terlihat dari tingkat signifikansi $\mathrm{F}$ yang sebesar $0,000<0,05$.

\section{KESIMPULAN DAN SARAN}

Berdasarkan penelitian tentang pengaruh emotional exhaustion dan budaya kerja terhadap kinerja guru studi kasus pada SDN wilayah Kecamatan Tandes, maka diperoleh kesimpulan sebagai berikut:

1. Dari hasil analisis regresi linier berganda nilai konstanta bernilai positif artinya jika skor variabel emotional exhaustion, dan budaya kerja dianggap tidak ada atau sama dengan nol, maka skor kinerja guru akan semakin bertambah. Koefisien regresi variabel emotional exhaustion menunjukkan nilai positif yang artinya jika emotional exhaustion yang diberikan semakin bagus maka kinerja guruakan meningkat. Koefisien regresi variabel budaya kerja menunjukkan nilai positif yang artinya jika budaya kerja yang diberikan semakin bagus maka kinerja guruakan meningkat. Kedua variabel independen yang di uji secara individual yang memiliki nilai yang lebih tinggi atau yang lebih besar dari variabel lain adalah variabel emotional exhaustion.

2. Variabel emotional exhaustion (X1), dan budaya kerja (X2) secara simultan berpengaruh positif dan signifikan terhadap variabel kinerja guru $(\mathrm{Y})$.

3. Variabel emotional exhaustion (X1) memiliki pengaruh positif dan signifikan terhadap kinerja guru (Y). Hal ini menunjukkan bahwa jika semakin baik kelelahan emosional maka kinerja guru semakin meningkat.

4. Variabel budaya kerja (X2) memiliki pengaruh positif dan signifikan terhadap kinerja guru (Y). Hal ini ini berarti jika budaya kerja semakin baik maka akan meningkatkan pula kinerja guru.

Berdasarkan latar belakang, rumusan masalah, hipotesis, interprestasi, serta kesimpulan yang diambil, maka saran yang dapat direkomendasikan adalah sebagai berikut:

1. Sekolah perlu memperhatikan kelelahan emosional, dan budaya kerja para guru agar sekolah semakin lama semakin berkembang. 
2. Dari hasil penelitian diketahui bahwa variabel emotional exhaustionmemiliki pengaruh paling besar, hal ini dianggap wajar karena para siswa akan nyaman belajar jika emosional guru sedang stabil.

3. Karena keterbatasan waktu, tenaga, dan biaya yang dimiliki penulis pada penelitian ini, maka diharapkan untuk penelitian yang akan datang berkaitan kinerja guru, disarankan untuk mengembangkan penelitian ini dengan mengurangi atau menambah variabel-variabel lain yang belum digunakan dalam penelitian ini. Karena masih banyak variabel-variabel yang ikut mempengaruhi budaya kerja tidak dimasukkan dalam penelitian ini.

\section{DAFTAR PUSTAKA}

Arianto, D.A.N. (2013). Pengaruh Kedisiplinan, Lingkungan Kerja Dan Budaya Kerja Terhadap Kinerja Tenaga Pengajar. Jurnal Economia, 9(2), 191-200

Churiyah, M. (2007). Pengaruh Konflik Peran (Role Conflict) terhadap Kepuasan Kerja Perawat serta Komitmen Pada Organisasi. Modernisasi,3(1): 43-53.

Churiyah, M. (2011). Pengaruh Konflik Peran, Kelelahan Emosional terhadap Kepuasan Kerja dan Komitmen Organisasi. Jurnal Ekonomi Bisnis, 16(2), 145-154.

Kurniasih, I., dan Sani, B. (2014). Implementasi Kurikulum 2013 Konsep dan Penerapan. Surabaya: Kata Pena.

Kusriyani, T., Magdalena, M., \& Paramita, P. D. (2016). Pengarauh Konflik Peran, Kelelahan Emosional, dan Kepuasan Kerja Terhadap Intensitas Turnover yang Dimediasi Komitmen Organsisasi Pada Dinas Pasar Kota Semarang. Journal of Management, 8(1), 87-99.

Mangkunegara. (2011). Manajemen Sumber Daya Perusahaan. Bandung: PT. Remaja Rosdakarya.

Maslach, C.; Jackson, S.E. \& Leiter, M. P. (1996). MBI: The Maslach Burnout Inventory: Manual. Palo Alto, CA: Consulting Psychologists Press.

Moeheriono. (2012). Pengukuran Kinerja Berbasis Kompetensi. Jakarta: Raja Grafindo Persada.

Rivai, A., dan Prawironegoro, D. (2015). Manajemen Strategis (Kajian Manajemen Strategis Berdasar Perubahan Lingkungan Bisnis, Ekonomi, Sosial dan Politi). Jakarta: Mitra Wacana Media.

Safrizal, M. S., dan Chan, S. (2014). Pengaruh Budaya Kerja, Kemampuan dan Komitmen Pegawai Terhadap Kinerja Pegawai Serta Dampaknya Pada Kinerja Dinas Pertambangan dan Energi Aceh. Jurnal Manajemen, 3(2), 44-53

Schaufeli, W. \& Enzmann, D. (1998). The burnout companion to study and practice. A critical analysis. London: Taylor \& Francis.

Schein, Edgar H. (2014). Organizational Culture and Leadership. San Francisco: JoseyBass Publishers.

Sudirno, H. D., \& Nurvianti, D. V. (2015). Konflik Peran Dan Kelelahan Emosional Pengaruhnya Terhadap Kinerja Dosen Pada Universitas Majalengka. Maksi, 2(1), 1-18

Sudjana, Nana. (2010). Cara Belajar Siswa Aktif dalam Proses Belajar Mengajar. Bandung: Sinar Baru Algensindo

Supardi. 2014. Kinerja Guru. Jakarta: PT Raja Grafindo Persada 
Widhaswara, Y. (2017). Pengaruh Budaya Kerja, Lingkungan Kerja Dan Stres Kerja Terhadap Kinerja Karyawan PT Suling Mas Tri Tunggal Abadi Tulungagung. Simki-Economic, 01(03), 1-13.

Yuliastini, N. W. D., dan Putra, M. S. (2015). Pengaruh kelelahan emosional terhadap kepuasan kerja guru smk di denpasar. E-Jurnal Manajemen Unud, 4(4), 943-959 